\title{
Task 8 - Management and Reporting
}

\author{
Semi-Annual Report \\ November 1, 1996 - March 31, 1997
}

\section{By: \\ Daniel J. Daly Thomas A. Erickson}

Work Performed Under Contract No.: DE-FC21-94MC31388

For

U.S. Department of Energy.

Office of Environmental Management

Office of Technology Development

1000 Independence Avenue

Washington, DC 20585
RECEIVED

NOV $1 ? 1997$

OSTI

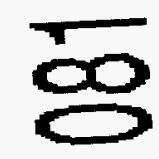

U.S. Department of Energy

Office of Fossil Energy

Federal Energy Technology Center

Morgantown Site

P.O. Box 880

Morgantown, West Virginia 26507-0880
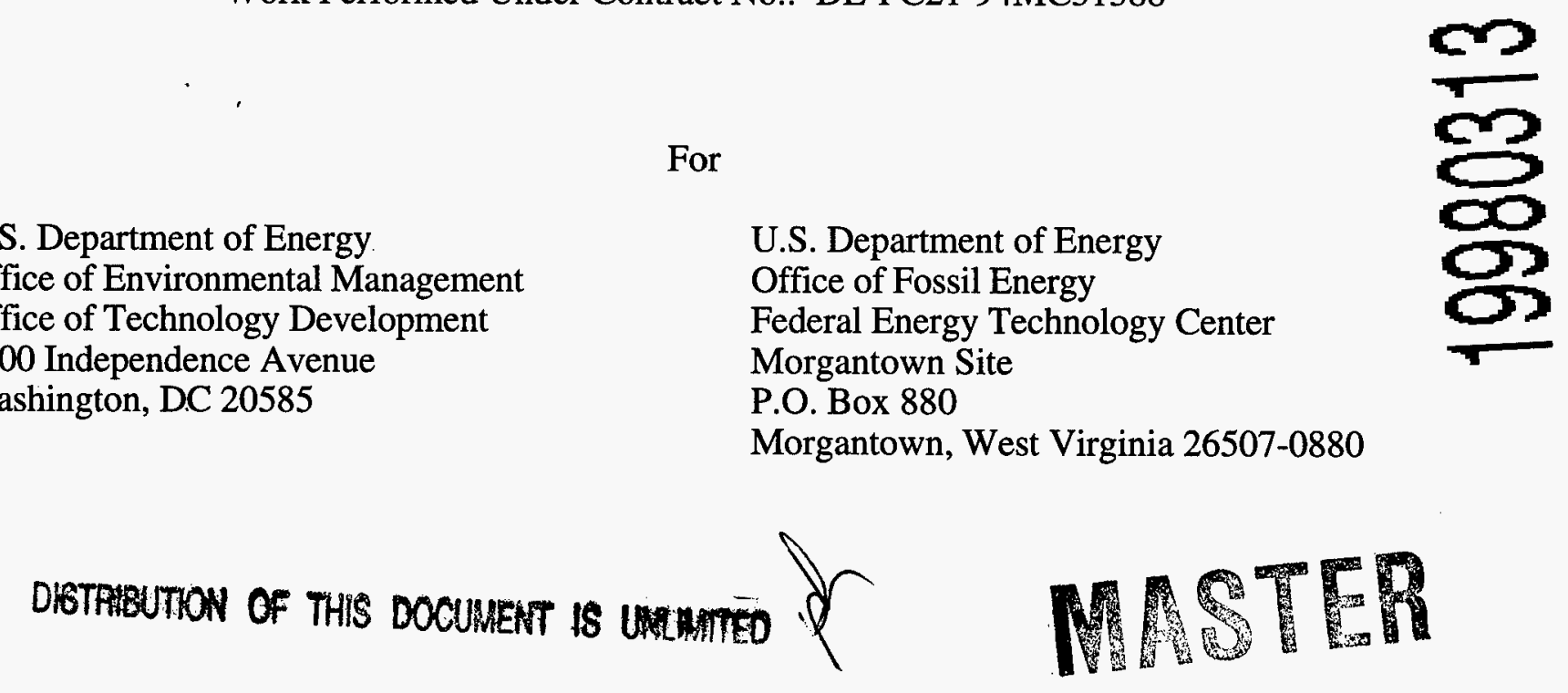

By

Energy \& Environmental Research Center

University Of North Dakota

P.O. Box 9018

Grand Forks, North Dakota 58202-9018 


\section{Disclaimer}

This report was prepared as an account of work sponsored by an agency of the United States Government. Neither the United States Government nor any agency thereof, nor any of their employees, makes any warranty, express or implied, or assumes any legal liability or responsibility for the accuracy, completeness, or usefulness of any information, apparatus, product, or process disclosed, or represents that its use would not infringe privately owned rights. Reference herein to any specific commercial product, process, or service by trade name, trademark, manufacturer, or otherwise does not necessarily constitute or imply its endorsement, recommendation, or favoring by the United States Government or any agency thereof. The views and opinions of authors expressed herein do not necessarily state or reflect those of the United States Government or any agency thereof. 


\section{DISCLAIMER}

This semiannual report was prepared as an account of work sponsored by an agency of the United States Government. Neither the United States Government, nor any agency thereof, nor any of their employees makes any warranty, express or implied, or assumes any legal liability or responsibility for the accuracy, completeness, or usefulness of any information, apparatus, product, or process disclosed or represents that its use would not infringe privately owned rights. Reference herein to any specific commercial product, process, or service by trade name, trademark, manufacturer, or otherwise does not necessarily constitute or imply its endorsement, recommendation, or favoring by the United States Government or any agency thereof. The views and opinions of authors expressed herein do not necessarily state or reflect those of the United States Government or any agency thereof.

\section{EERC DISCLAIMER}

This semiannual report was prepared by the Energy \& Environmental Research Center (EERC), an agency of the University of North Dakota, as an account of work sponsored by the U.S. Department of Energy Federal Energy. Technology Center. Because of the research nature of the work performed, neither the EERC nor any of its employees makes any warranty, express or implied, or assumes any legal liability or responsibility for the accuracy, completeness, or usefulness of any information, apparatus, product, or process disclosed or represents that its use would not infringe privately owned rights. Reference herein to any specific commercial product, process, or service by trade name, trademark, manufacturer, or otherwise does not necessarily constitute or imply its endorsement or recommendation by the EERC.

\section{ACKNOWLEDGMENT}

This semiannual report was prepared with the support of the U.S. Department of Energy (DOE) Federal Energy Technology Center Cooperative Agreement No. DE-FC21-94MC31388. However, any opinions, findings, conclusions, or recommendations expressed herein are those of the author(s) and do not necessarily reflect the views of DOE. 


\section{TABLE OF CONTENTS}

LIST OF TABLES $\ldots \ldots \ldots \ldots \ldots \ldots \ldots \ldots \ldots \ldots \ldots \ldots \ldots \ldots \ldots$

1.0 INTRODUCTION $\ldots \ldots \ldots \ldots \ldots \ldots \ldots \ldots \ldots \ldots \ldots \ldots \ldots \ldots \ldots \ldots$

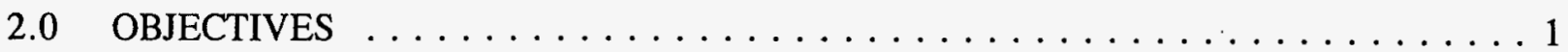

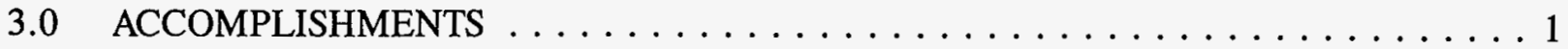

4.0 WORK PLANNED FOR NEXT 6 MONTHS $\ldots \ldots \ldots \ldots \ldots \ldots$ FETC-EERC ENVIRONMENTAL MANAGEMENT COOPERATIVE AGREEMENT

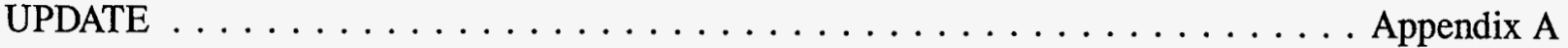

\section{LIST OF TABLES}

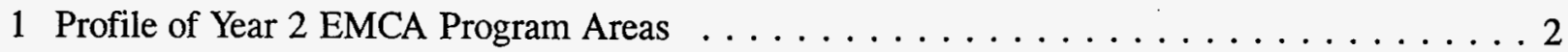

2 FY97 Technology Commercialization Activities under the FETC-EERC EM Cooperative

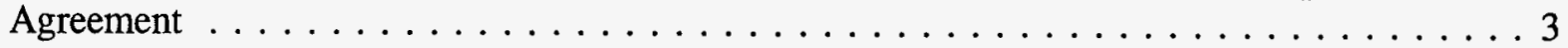

3 Matrix of EERC Core Expertise and EM Technology Needs $\ldots \ldots \ldots \ldots \ldots$ 


\section{TASK 8 - MANAGEMENT AND REPORTING}

\subsection{INTRODUCTION}

The task of restoring nuclear defense complex sites under the U.S. Department of Energy (DOE) Environmental Management (EM) Program presents an unprecedented challenge to the environmental restoration community. Effective and efficient cleanup requires the timely development or modification of novel cleanup technologies applicable to radioactive wastes. Fostering the commercialization of these innovative technologies is the mission of EM-50, the EM Program Office of Science and Technology. DOE's Federal Energy Technology Center (FETC) pursues activities integral to the EM-50 mission through its Cooperative Agreement with the EM Office of Science and Technology.

On the road to commercialization, innovative technologies must overcome significant barriers with respect to technical issues, proof of performance, partnering, capitalization, and regulatory acceptance. The Energy \& Environmental Research Center (EERC), a not-for-profit, contractsupported organization focused on research, development, demonstration, and commercialization (RDD\&C) of energy and environmental technologies, has entered the third year of a Cooperative Agreement with FETC designed to 1) overcome key barriers through technical support, real-world demonstrations, and partnering; and 2) support the integration and deployment of "winner" technologies at EM sites. These activities, along with program management, make up the program areas of the FETC-EERC EM Cooperative Agreement (EMCA): Technology Commercialization, Technology Integration, and Management and Reporting. These areas are profiled in Table 1.

This report addresses the Management and Reporting program area, Task 8, under EMCA.

\subsection{OBJECTIVES}

The primary objective of Task 8 is to ensure the effectiveness of the EMCA. This is accomplished through 1) the coordination of internal EMCA activities and coordination with the FETC contractor's representative, 2) the coordination and expansion of the EMCA, and 3) effective technical transfer.

\subsection{ACCOMPLISHMENTS}

Specific activities under Task 8, Management and Reporting, are summarized below: 


\section{TABLE 1}

Profile of Year 2 EMCA Program Areas

\begin{tabular}{|c|c|c|}
\hline Program Area & Description & EMCA Tasks \\
\hline $\begin{array}{l}\text { Technology } \\
\text { Commercialization }\end{array}$ & $\begin{array}{l}\text { Technical support, performance } \\
\text { testing, and brokering }\end{array}$ & $\begin{array}{l}\text { Eight activities involving } \\
\text { public-private partnerships } \\
\text { (see Table 2) }\end{array}$ \\
\hline Technology Integration & $\begin{array}{l}\text { Provide support for the } \\
\text { appropriate deployment of } \\
\text { cleanup technologies at EM sites }\end{array}$ & $\begin{array}{l}\text { Task } 10 \text { (subcontract to Waste } \\
\text { Policy Institute) }\end{array}$ \\
\hline $\begin{array}{l}\text { Management and } \\
\text { Reporting }\end{array}$ & $\begin{array}{l}\text { - Program management } \\
\text { - Liaison with FETC } \\
\text { - Program development } \\
\text { - Technology transfer }\end{array}$ & Task 8 \\
\hline
\end{tabular}

- The Year 3 Continuation Application was developed and approved by FETC. Activities commenced in early December 1996. As shown in Appendix A and Table 2, four activities were continued, and four activities were added:

- Activities were initiated with two FETC industry partners, Science and Engineering Associates and Vortec Corporation, as a result of an intensive marketing effort carried out during the summer of 1996.

- Two activities were added based on a review of in-house technology partnerships (Baumgartner Environics Incorporated Bubbleless Gas Transfer and Subcritical Water).

- Two task activities involve technologies already deployed in the DOE complex (Task 9 and Task 16); one was near commercial (Task 2); three tasks involve technologies in advanced stages of development (Tasks 3, 12, and 13); and two tasks deal with technologies in early stages of development (Task 14 and 15). During the course of the reporting period, Suprex Corporation (Task 2) was acquired by ISCO of Lincoln, Nebraska, which did not wish to market the Task 2 SFE technology. As a result, Task 2 was discontinued in January 1997, and efforts were begun to utilize the remaining funds to work on a technology being developed by Weiss Associates.

- Negotiations continue to acquire industry partners for Task 3 and 15 activities.

- Systems Engineering (Task 11) was discontinued as a discrete task and was instead made an integral part of all technology task activities.

- Technology Integration (Task 10) was discontinued with the completion of the WPI subcontract. 
TABLE 2

FY97 Technology Commercialization Activities under the FETC-EERC EM Cooperative Agreement

\begin{tabular}{|c|c|c|c|}
\hline Task & Technology & Commercial Partner & EERC Activity \\
\hline 2 & $\begin{array}{l}\text { Field SFE and FieldSFE/FT } \\
\text { IR for Extraction and Analysis of } \\
\text { Organic Pollutants }\end{array}$ & Suprex Corporation & $\begin{array}{l}\text { Field demonstration of SFE, } \\
\text { develop and commercialize field } \\
\text { portable SFE/FT IR instrument }\end{array}$ \\
\hline 3 & $\begin{array}{l}\text { Field-Portable Unit for Thermal } \\
\text { Decomposition for Organic } \\
\text { Mixed Wastes Including } \\
\text { Resins }\end{array}$ & $\begin{array}{c}\text { Developed with American Plastics } \\
\text { Council and other industry } \\
\text { partners }\end{array}$ & $\begin{array}{l}\text { Develop, demonstrate, and } \\
\text { commercialize a fluid-bed } \\
\text { technology for } \\
\text { organic/radionuclide separations } \\
\text { and organic waste treatment }\end{array}$ \\
\hline 9 & $\begin{array}{l}\text { Centrifugal Membrane } \\
\text { Filtration for Aqueous Stream } \\
\text { Treatment }^{2}\end{array}$ & SpinTek Membrane Systems Inc. & $\begin{array}{l}\text { Optimize SpinTek Membrane } \\
\text { Systems Inc. filtration technology } \\
\text { for EM applications }\end{array}$ \\
\hline 12 & Automated Laser-Based Unit & r l Associates & $\begin{array}{l}\text { Optimize sensors and } \\
\text { decontamination characteristics, } \\
\text { evaluate economics }\end{array}$ \\
\hline 13 & $\begin{array}{l}\text { Fiber Optic Cone Penetrometer } \\
\text { System for Subsurface Metal } \\
\text { Detection }\end{array}$ & science \& Engineerng Associates & Sensor calibration and validation \\
\hline 14 & $\begin{array}{l}\text { Bubbleless Gas-Transfer } \\
\text { Technology for In Situ } \\
\text { Bioremediation of Chlorinated } \\
\text { Hydrocarbons }\end{array}$ & $\begin{array}{l}\text { Baumgartner Environics } \\
\text { Incorporated }\end{array}$ & $\begin{array}{l}\text { Laboratory column and batch } \\
\text { testing and evaluation }\end{array}$ \\
\hline ॰ & $\begin{array}{l}\text { Subcritical Water Technology } \\
\text { for Treatment of Hydrocarbon } \\
\text { Contaminated Soil }\end{array}$ & ' & Process development and pilot \\
\hline 16 & Waste Vitrification Facility ${ }^{2}$ & Vortec Corporation & $\begin{array}{l}\text { Sampling plans for feedstock and } \\
\text { emissions; sampling plan for } \\
\text { QA/QC for RCRA materials of } \\
\text { interest and product leachability }\end{array}$ \\
\hline
\end{tabular}

\footnotetext{
Task discontinued.

${ }^{2}$ Currently on EM site.
}

- As a result of conversations with Mr. Roger Wetzel of Energetics, a Technology Development Data Sheet (TDDS) was completed for the overall EMCA program and forwarded to Mr. Roger Wetzel of Energetics in the fall of 1996 and in March of 1997. The TDDS will continue to be updated on a quarterly basis to match the FETC TDDS publication schedule. 
- An evaluation of EERC core expertise with respect to EM technology needs was updated to reflect the revised EM nomenclature and proposed Year 3 activities. Results of this evaluation are shown in Table 3. This evaluation will continue to be used to guide the development of opportunities under the Technology Commercialization area.

\section{TABLE 3}

Matrix of EERC Core Expertise and EM Technology Needs

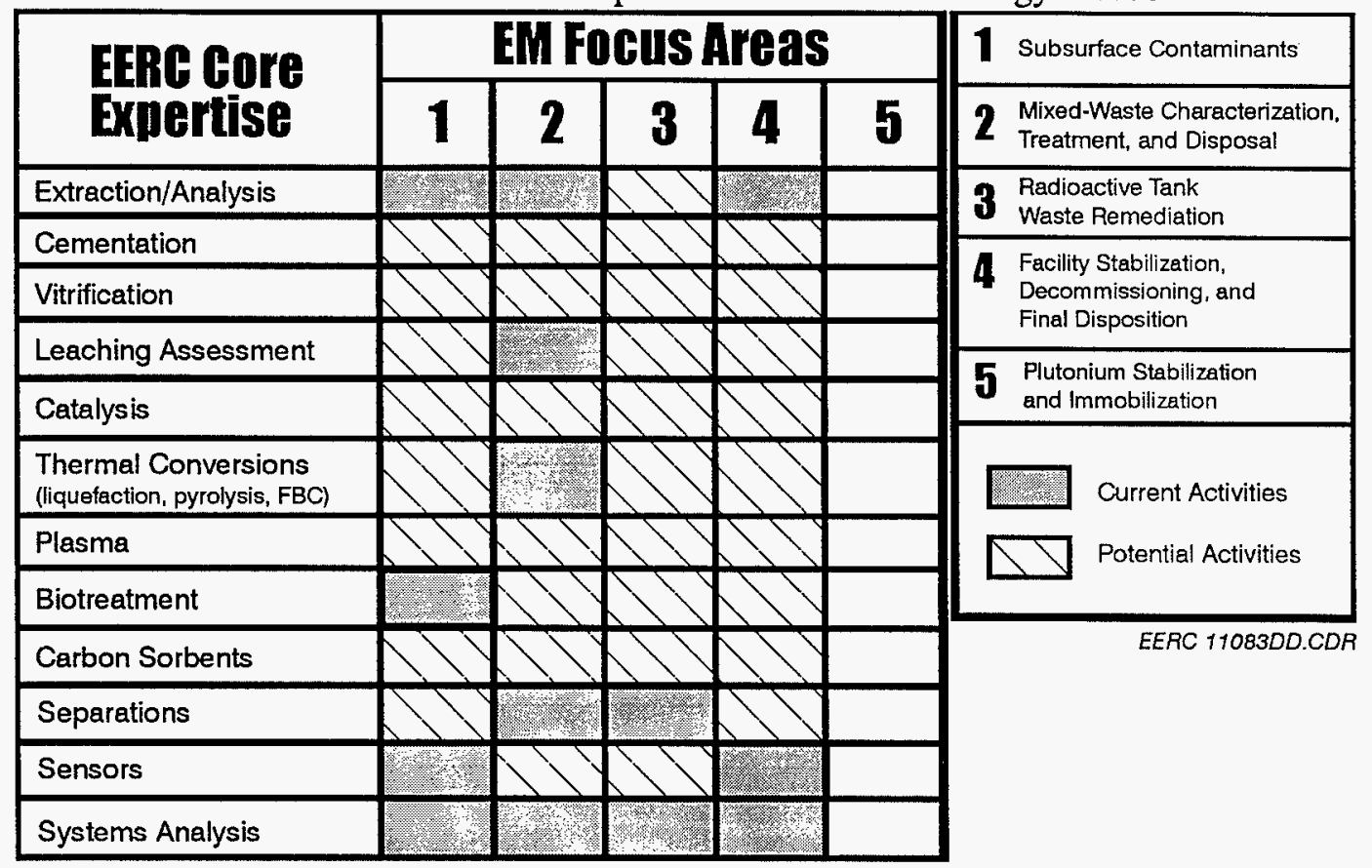

\subsection{WORK PLANNED FOR NEXT 6 MONTHS}

Efforts during the period April 1, 1997, through September 30, 1997, will focus on the following: 1) update TDDS quarterly; 2) continue to identify commercial partners, promising technologies, and outreach opportunities; 3 ) continue efforts to team with EM sites to match needs with technologies and provide demonstration venues; and 4) continue enhancement of Task 8 effectiveness. 
APPENDIX A

\section{FETC-EERC ENVIRONMENTAL MANAGEMENT COOPERATIVE AGREEMENT UPDATE}


FETC-EERC ENVIRONMENTAL MANAGEMENT COOPERATIVE AGREEMENT

TASK SUMMARY

\begin{tabular}{|c|c|c|c|}
\hline 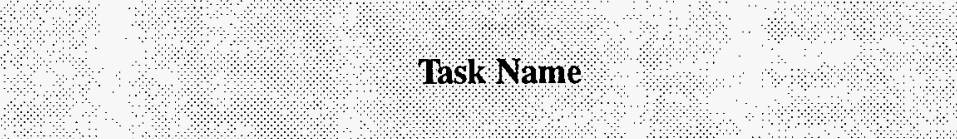 & Numble, & $\begin{array}{l}\text { Period of } \\
\text { Performance }\end{array}$ & $\begin{array}{l}\text { Total } \\
\text { Cost } \\
(\$ 1000)\end{array}$ \\
\hline $\begin{array}{l}\text { Provide Information Required for Compliance with the National } \\
\text { Environmental Policy Act (NEPA) }\end{array}$ & 1 & Sept. 94 - Sept. 95 & 5 \\
\hline Extraction and Analysis of Pollutant Organics & 2 & Sept. 94 - Jan. 97 & 430 \\
\hline Pyrolysis of Plastic Waste & 3 & Sept. 94 - Sept. 96 & 590 \\
\hline $\begin{array}{l}\text { Stabilization of Vitrified Waste by Enhanced Crystallization and } \\
\text { Development of a Protocol to Predict Long-Term Stability }\end{array}$ & 4 & Sept. 94 - Sept. 95 & 80 \\
\hline $\begin{array}{l}\text { Extraction of Hazardous Metals from Mixed Solid Wastes by } \\
\text { Chelation and Supercritical Fluid Extraction }\end{array}$ & 5 & NA & NA \\
\hline Subcritical Water Extraction of Organic Pollutants & 6 & NA & NA \\
\hline $\begin{array}{l}\text { Demonstration of a Low-Temperature Plasma Remediation } \\
\text { Technology }\end{array}$ & 7 & NA & NA \\
\hline Management and Reporting & 8 & Sept. 94 - Dec. 97 & 235 \\
\hline Centrifugal Membrane Filtration & 9 & Sept. 94 - Dec. 97 & 433 \\
\hline Technology Development Integration & 10 & July 95 - Dec. 97 & $14,309 *$ \\
\hline Systems Analysis of Environmental Management Technologies & 11 & April 96 - Dec. 97 & 641 \\
\hline Laser Cleaning of Contaminated Painted Surfaces & 12 & Sept. 95 - Dec. 97 & 240 \\
\hline Cone Penetrometer for Subsurface Metal Detection & 13 & Dec. 96 - Dec. 97 & 230 \\
\hline Bubbleless Gas-Transfer Technology & 14 & Dec. 96 - Dec. 97 & 140 \\
\hline $\begin{array}{l}\text { Remediation of Organically Contaminated Soil Using Hot/Liquid } \\
\text { (Subcritical) Water }\end{array}$ & 15 & Dec. 96 - Dec. 97 & 140 \\
\hline $\begin{array}{l}\text { Preparation of Sampling/Analysis and Availability Assurance Plans } \\
\text { for the Vortec Vitrification Demonstration Plant }\end{array}$ & 16 & Dec. 96 - Dec. 97 & 41 \\
\hline Total $(\$ 1000)$ & & & $\$ 17,514$ \\
\hline
\end{tabular}

* Includes WPI subcontract of $\$ 13,644.00$. 
FETC-EERC ENVIRONMENTAL MANAGEMENT COOPERATIVE AGREEMENT

COMMERCIAL PARTNERS

\begin{tabular}{|c|c|c|}
\hline \multirow[b]{2}{*}{ Task Name } & \multicolumn{2}{|c|}{ Small Business Partner } \\
\hline & $\begin{array}{l}\text { FETC Industry } \\
\text { Partner }\end{array}$ & $\begin{array}{l}\text { EERC Industry } \\
\text { Partner }\end{array}$ \\
\hline $\begin{array}{l}\text { Provide Information Required for Compliance with the National } \\
\text { Environmental Policy Act (NEPA) }{ }^{1,2}\end{array}$ & NA & NA \\
\hline Extraction and Analysis of Pollutant Organics ${ }^{3}$ & & Suprex Corporation \\
\hline Pyrolysis of Plastic Waste & \multicolumn{2}{|c|}{ Negotiations in progress } \\
\hline $\begin{array}{l}\text { Stabilization of Vitrified Waste by Enhanced Crystallization and } \\
\text { Development of a Protocol to Predict Long-Term Stability }{ }^{2,3}\end{array}$ & NA & NA \\
\hline Management and Reporting ${ }^{1}$ & NA & NA \\
\hline Centrifugal Membrane Filtration & $\begin{array}{l}\text { SpinTek Membrane } \\
\text { Systems, Inc. }\end{array}$ & \\
\hline Technology Development Integration ${ }^{1,2}$ & NA & NA \\
\hline Systems Analysis of Environmental Management Technologies ${ }^{4}$ & NA & NA \\
\hline Laser Cleaning of Contaminated Painted Surfaces & F2 Associates, Inc. & \\
\hline Cone Penetrometer for Subsurface Metal Detection ${ }^{5}$ & $\begin{array}{l}\text { Science \& } \\
\text { Engineering } \\
\text { Associates }\end{array}$ & \\
\hline Bubbleless Gas-Transfer Technology ${ }^{5}$ & & $\begin{array}{l}\text { Baumgartner } \\
\text { Environics Inc. }\end{array}$ \\
\hline $\begin{array}{l}\text { Remediation of Organically Contaminated Soil Using } \\
\text { Hot/Liquid (Subcritical) }\end{array}$ & \multicolumn{2}{|c|}{ To be determined } \\
\hline $\begin{array}{l}\text { Preparation of Sampling/Analysis and Availability Assurance } \\
\text { Plans for the Vortec Vitrification Demonstration Plant }\end{array}$ & Vortec Corporation & \\
\hline
\end{tabular}

${ }^{1}$ Does not require industry partner.

${ }^{2}$ Completed.

${ }^{3}$ Discontinued.

${ }^{4}$ Integrated into technical activities.

${ }^{5}$ New in Year 3. 
FETC-EERC ENVIRONMENTAL MANAGEMENT COOPERATIVE AGREEMENT

PRIMARY AND SECONDARY APPLICATIONS FOR EM FOCUS AREAS

\begin{tabular}{|c|c|c|c|c|c|}
\hline \multirow[b]{2}{*}{ Task Name } & \multicolumn{5}{|c|}{ DOE EM Focus Areas } \\
\hline & Subsurface & $\begin{array}{l}\text { Mixed Wastet: } \\
\text { Characterization, } \\
\text { Treatment, and } \\
\text { Disposal }\end{array}$ & $\begin{array}{l}\text { Radioactive Tank } \\
\text { Waste } \\
\text { Remediation }\end{array}$ & $\begin{array}{l}\text { Facility Stabilization, } \\
\text { Decommissioning, and } \\
\text { Final Disposition }\end{array}$ & $\begin{array}{l}\text { Plutonium } \\
\text { Stabilization and } \\
\text { Immobilization }\end{array}$ \\
\hline Extraction and Analysis of Pollutant Organics & $P$ & - & - & 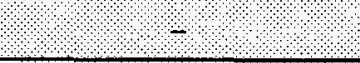 & - \\
\hline Pyrolysis of Plastic Waste & 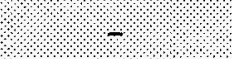 & P & 4 & $x$ & - \\
\hline $\begin{array}{l}\text { Stabilization of Vitrified Waste by Enhanced } \\
\text { Crystallization and Development of a Protocol to } \\
\text { Predict Long-Term Stability }\end{array}$ & 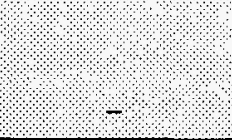 & $\mathrm{x}$ & $\mathrm{x}$ & $\mathrm{P}$ & - \\
\hline Centrifugal Mernbrane Filtration & P & ? & $\mathrm{x}$ & ?. & ?. \\
\hline $\begin{array}{l}\text { Laser Cleaning of Contaminated Painted } \\
\text { Surfaces }\end{array}$ & t. & 1. & - & P & - \\
\hline $\begin{array}{l}\text { Cone Penetrometer for Subsurface Metal } \\
\text { Detection }\end{array}$ & P. & . & - & - & ?. \\
\hline Bubbbleless Gas-Transfer Technology? & $\mathrm{P}$ & - & - & $=$ & - \\
\hline $\begin{array}{l}\text { Remediation of Organically Contaminated Soil } \\
\text { Using Hot/Liquid (Subcritical) Water }\end{array}$ & $\mathrm{P}$ & 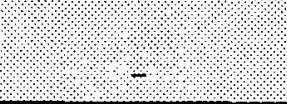 & 3 & . & - \\
\hline $\begin{array}{l}\text { Preparation of Sarnpling/Analysis and } \\
\text { Availability Assurance Plans for the Vortec } \\
\text { Vitrification Demonstration Plant }\end{array}$ & - & P & - & - & s. \\
\hline
\end{tabular}




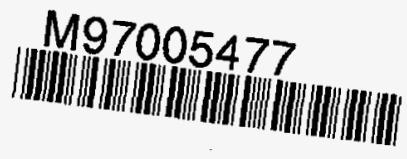

Report Number (14) DOE/MC/31388- = 5779

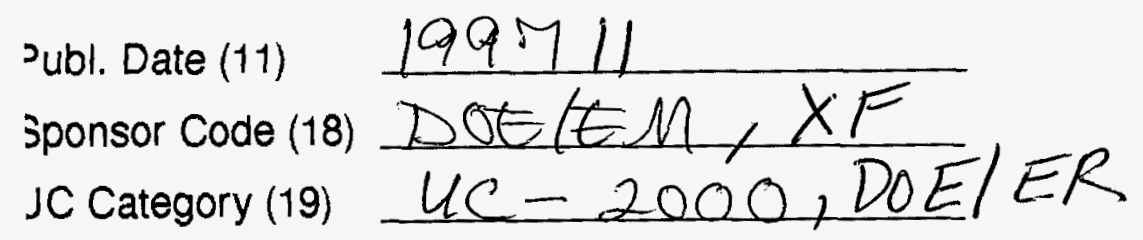

